\title{
Perwujudan Ekaristi pada Interior Gereja Katolik Hati Santa Perawan Maria Tak Bernoda, Tangerang
}

\author{
Regina Cesilia Velika ${ }^{1}$, Djauhari Sumintardja ${ }^{2}$, Augustina Ika Widyani ${ }^{3}$ \\ Prodi Desain Interior, Fakultas Seni Rupa dan Desain, Universitas Tarumanagara \\ Jl. Letjen S. Parman No. 1 Jakarta Barat 11440, Indonesia \\ regina.615150119@stu.untar.ac.id,dsumintardja@gmail.com, augustinaw@fsrd.untar.ac.id
}

\begin{abstract}
Gereja merupakan tempat bersekutu umat kristiani untuk beribadah kepada Tuhan. Gereja Katolik Hati Santa Perawan Maria Tak Bernoda sendiri memiliki nilai-nilai yang diambil dari keutamaan Maria sebagai perawan tak bernoda, yaitu mengedepankan nilai-nilai kekeluargaan, keteduhan, dan kedamaian. Oleh karena itu, perancangan interior Gereja Katolik Hati Santa Perawan Maria Tak Bernoda akan mengambil nilai-nilai tersebut untuk diterjemahkan ke dalam konsep perancangan interiornya. Melalui metode perancangan yang didasari pada penelusuran data termasuk identifikasi masalah desainnya serta dilanjutkan dengan analisis dan sintesis desain, perancangan interior ini ditujukan untuk menghadirkan suasana kekeluargaan yang akan mengayomi setiap jamaat yang hadir. Perancangan spasial mengacu pada prosesi keagamaan yang merupakan kegiatan utama pada gereja, sehingga nilai-nilai kekeluargaan, keteduhan dan kedamaian merupakan pendukung dari suasana gereja sebagai tempat ibadah yang sakral dan khusyuk. Kekuatan suasana ruang interior akan mempengaruhi psikologi pengguna ruang sehingga muncul keterikatan umat dengan gereja. Rasa khusyuk dalam ruang ibadah dibutuhkan untuk memberikan suasana sakral dan suci sehingga umat yang beribadah dapat merasakan hadirat Tuhan dekat dengan mereka. Konsep Ekaristi yang diterapkan pada desain interior Gereja Katolik Santa Maria Tak Bernoda ini menghadirkan suasana akrab kekeluargaan sebagaimana suasana yang hadir pada peristiwa perjamuan malam.
\end{abstract}

Kata kunci: Elemen Ruang, Interior Gereja, Katolik, Keluarga, Sakral.

\section{PENDAHULUAN}

Gereja Katolik Hati Santa Perawan

Maria terletak di Tangerang, Jawa Barat.

Jemaatnya terdiri dari berbagai latar

belakang suku dan kebudayaan yang

berbeda, namun demikian mampu

bersekutu bersama untuk memuliakan

Tuhan dalam harmoni kebersamaan yang

beragam.

Dengan keberagaman jemaat gereja, desain interior gereja memerlukan pertimbangan tersendiri untuk mendukung kebersamaan di antara jemaatnya. Perancangan interior gereja yang baik adalah yang mampu menghadirkan suasana peribadatan yang sakral, kudus, dan membawa umat lebih lagi dekat kepada Tuhan. Dalam mencapai hal-hal tersebut, perlu adanya konsep liturgi serta penerapan karakteristik gereja yang sesuai dengan visi-misi gereja.

Terdapat beberapa permasalahan desain dalam perancangan Gereja Hati 
Santa Perawan Maria Tak Bernoda Tangerang antara lain sebagai berikut. Salah satunya adalah bagaimana perancangan interior Gereja Hati Santa Perawan Maria Tak Bernoda dengan suasana yang sesuai dengan tema ekaristi (Perjamuan Malam Tuhan).

\section{METODE}

Metode yang digunakan pada penelitian ini adalah metode kualitatif dengan menerapkan proses desain dalam menghasilkan usulan-usulan sesuai dengan rumusan masalah.

Pengumpulan data dilakukan dengan literatur mengenai gereja dan konsep ekaristi, wawancara terhadap jemaat Gereja Hati Santa Perawan Maria Tak Bernoda, serta observasi dan dokumentasi di lokasi gereja.

Data yang dikumpulkan tersebut kemudian dianalisis untuk menghasilkan konsep desain dengan tahapan perancangan sebagaimana proses desain yang dijabarkan oleh Kilmer (Kilmer \& Kilmer, 2014) berikut:

1) Programming, memilih dan memilah data berdasarkan rumusan masalah.

2) Konsep desain, menyusun solusi desain berdasarkan kebutuhan ruang dan karakter Gereja yang bersangkutan.

3) Mengembangkan dan mengeksplorasi alternatif desain berdasarkan program ruang dan konsep desain.

4) Menyusun gambar kerja termasuk di dalammya adalah rencana furnitur, rencana lantai, detail konstruksi interior, detail konstruksi furniture dan aksonometri.

5) Menyusun gambar presentasi dengan menggunakan arsir dan warna sesuai pemilihan material pada perancangan Gereja Hati Santa Perawan Maria Tak Bernoda.

\section{HASIL DAN PEMBAHASAN}

Kata "Gereja" berasal dari kata igreja dibawa oleh para misionaris Portugis. Kata igreja merupakan ejaan Portugis untuk kata Latin ecclesia yang ternyata berasal dari bahasa Yunani ekklesia (Nurwardani, 2016). Dalam bahasa Yunani ekklesia dapat berarti sebagai kumpulan, atau pertemuan atau rapat. Dalam bahasa Yunani ekklesia berasal dari kata yang berarti "memanggil". Oleh karena itu disimpulkan bahwa gereja adalah umat yang dipanggil Tuhan. 
Pada zaman para rasul, kata gereja disebut dengan kata "Gereja Allah" atau "jemaat Allah" yang dianggap sesuai dengan cara berbibaca orang Yahudi yang menurut 1 Korintus 11: $16-22$ di situ Paulus berbicara mengenai jemaat yang berkumpul dalam perayaan Ekaristi. Mereka menjadi "jemaat" atau "Gereja" karena iman mereka kepada Yesus Kristus, khususnya atas wafat dan kebangkitan-Nya. Gereja adalah "jemaat Allah yang dikuduskan dalam Kristus Yesus" (1 Korintus 1: 2). Ada 3 nama yang dipakai untuk Gereja dalam Perjanjian Baru (Perjanjian Baru, 2005), yaitu: Umat Allah, Tubuh Kristus, dan Bait Roh Kudus. Fungsi bangunan gereja adalah:
a. Tempat Pertemuan Persaudaraan,
b. Tempat Pengajaran Iman,
c. Tempat Adorasi dan Berdoa,
d. Tempat Merayakan Ekaristi,
e. Tempat Merayakan Sakramen - Sakramen,
f. Tempat Kenangan dan Tanda.

Gereja memilik 2 tugas penting, yang pertama adalah tugas penginjilan. Gereja ditugaskan oleh Allah sendiri untuk melakukan tugas penginjilan yang dituliskan di Alkitab "Pergilah, jadikanlah semua bangsa murid-Ku dan baptislah mereka dalam nama Bapa dan Anak dan Roh Kudus; dan ajarlah mereka melakukan segala sesuatu yang telah Kuperintahkan kepadamu. Dan ketahuilah Aku menyertai kamu senantiasa sampai akhir zaman" (Matius 28: 19-20). Dikatakan juga "Pergilah ke seluruh dunia, beritakanlah Injil kepada semua makhluk" (Markus 16: 15).

Tugas kedua gereja adalah tugas melayani. Melayani merupakan tugas setiap gereja di mana saja dan dengan berbagai cara. Pada masa sekarang ini sudah banyak gereja yang memberikan pertolongan pelayanan sosial gereja ke rumah sakit, yayasan sosial, panti asuhan dan sebagainya.

Bangunan gereja terdiri dari beberapa ruangan pokok, yaitu:

\section{A. Panti Imam (Sanctuary)}

Panti Imam merupakan tempat imam memimpin peribadatan. Pada panti imam terdapat altar yang menjadi pusat perhatian dalam gereja.

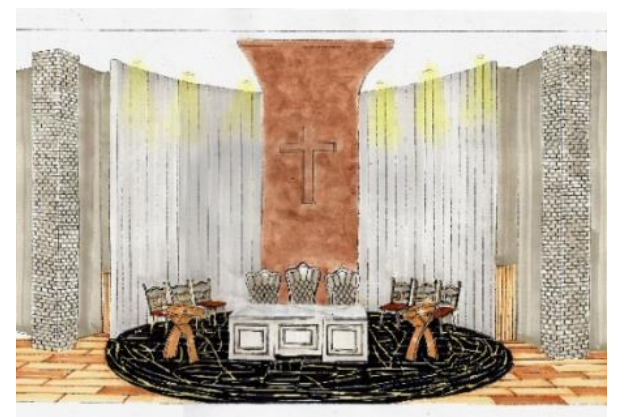

Gambar 1. Panti Imam dengan Orientasi Pada Altar (Sumber: Velika, 2018) 
Perlengkapan yang terdapat pada panti imam adalah:

1. Altar. Altar adalah meja persembahan.

2. Kanopi Altar (Altar Canopy)

3. Salib Altar. Di atas atau di dekat altar harus dipasang salib dengan figur Yesus.

4. Tabernakel. Tabernakel adalah lemari kecil tempat menyimpan hosti yang telah disucikan dan siap untuk dibagikan kepada umat pada upacara penerimaan komuni.

5. Lampu Abadi (Sanctuary lamp)

6. Meja Kredensa (Credence Table). Sebuah meja kecil yang diletakkan di salah satu panti imam untuk menempatkan perlengkapan ibadat.

7. Sedilia. Yaitu kursi tempat duduk diakon (pembantu imam) di sebelah meja kredensa.

8. Mimbar. Mimbar merupakan tempat imam membacakan khotbahnya diletakkan di panti imam atau di badan gereja.

B. Ruang Paduan Suara

Paduan suara berfungsi sebagai pemimpin dan pembangkit peran aktif dalam peribadatan.

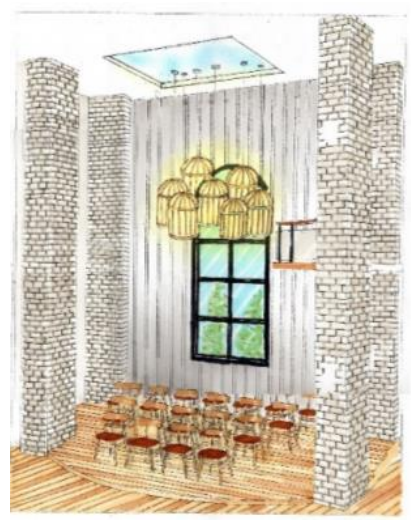

Gambar 2. Ruang Paduan Suara (Sumber: Velika, 2018)

C. Badan Gereja (Nave)

Badan gereja merupakan tempat umat beribadah. Badan gereja harus dekat dengan panti imam agar saling mudah melihat dan mendengar.

D. Serambi (Narthex/Vestibulum)

Serambi merupakan ruang perantara dari halaman/atrium ke dalam ruang utama gereja. Pada dinding dalam serambi serta pada setiap dinding setelah pintu masuk, baik badan gereja, ruang permandian, maupun sakristi, selalu ditempatkan bak air suci.

E. Ruang Permandian (Baptistry)

Ruang permandian dapat diletakkan di dalam bangunan induk gereja, atau terpisah menjadi bangunan sendiri. Letak yang paling baik adalah dekat serambi atau pintu masuk utama karena permandian merupakan sakramen 
pertama yang menandai seseorang diterima resmi sebagai anggota gereja.

F. Ruang Pengakuan (Confessionals)

Ruang adalah tempat seseorang mengaku dosa secara pribadi di depan imam sebagai perantara dalam suatu sakramen pengakuan dosa.

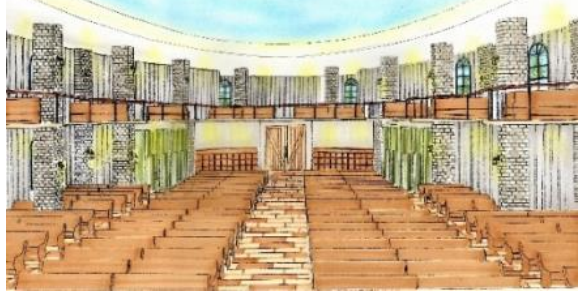

Gambar 3. Panti Umat dari Arah Altar (Sumber: Velika, 2018)

Gereja HSPMTB sebagai persekutuan dan gerakan umat Allah menjadi gereja yang ramah, sukacita, dan memasyarakat di Tanggerang. Menguatkan iman, harapan, dan kasih dalam keluarga, lingkungan dan masyarakat. Membangun umat Allah, hidup, sukacita, dan memerdekakan umat tangguh dalam iman, terlibat dalam persaudaraan inklusif, berbela rasa terhadap sesama dan lingkungan hidup.

Konsep umum perancangan Gereja sejarah keselamatan, oleh karena itu Bunda Maria menjadi perantara umat Katolik dan melalui Bunda Maria juga manusia memperoleh keselamatan dari Allah dalam diri Yesus Kristus Putera Allah yang menjadi manusia. Karena kelembutan hati dan kedekatannya kepada Allah, membuat bunda Maria menjadi tempat bagi anak-anaknya untuk datang memohon bantuan melalui doadoanya.
Katolik Hati Maria Tak Bernoda, disusun sebagai berikut:

\section{A. Tema Perancangan}

Konsep ekaristi yang diterapkan pada desain interior diteliti dari sudut pandang semiotika oleh Wardani (Wardani, 2006), menyimpulkan bahwa konsep liturgi ekaristi dimaksudkan untuk menuju ke arah realitas, yakni kehadiran Kristus yang menyelamatkan. 
Eucharist atau ekaristi adalah suatu ritus yang dipandang oleh kebanyakan gereja dalam Kekristenan sebagai suatu sakramen. Ekaristi dikenal juga sebagai Perjamuan Malam Tuhan (Indonesia, 2009). Perjamuan Malam Tuhan adalah sakramen yang diadakan oleh Tuhan Yesus sendiri pada saat menjelang akhir dari perayaan paskah yang dilakukan bersama murid-murid-Nya. Dalam perjamuan malam Tuhan, suasana yang tergambar adalah suasana hangat kekeluargaan ketika Tuhan berkumpul bersama dengan murid-murid-Nya, sukacita akan kehadiran Tuhan, sakral, penuh kenangan dan kudus.

\section{B. Konsep Organisasi Ruang}

Menurut teori hubungan-hubungan ruang (Ching, 2007), maka Gereja Katolik Hati Santa Perawan Maria Tak Bernoda memiliki hubungan ruang berikut ini:

a. Ruang di dalam ruang. Konsep hubungan ruang ini dapat dilihat pada ruang pengakuan dosa. Ruang pengakuan dosa terletak di area belakang tempat duduk umat dekat dengan pintu masuk utama gereja.

b. Ruang-ruang yang saling mengunci. Terdapat juga ruang yang saling mengunci seperti ruang persiapan yang terdapat di samping belakang panti imam.

c. Ruang-ruang yang berdekatan. Ruang yang berdekatan merupakan ruangan yang bersebelahan, sebagaimana dapat dilihat pada ruang sakristi dan ruang persiapan yang berada di belakang kursi umat.

d. Ruang yang dihubungkan oleh ruang bersama. Ruang bersama ini berfungsi sebagai ruang penghubung. Dalam kasus Gereja Hati Santa Perawan Maria Tak Bernoda konsep ruang ini dapat dilihat pada halaman gereja dengan ruang ibadat dengan area parkir sebagai penghubung karena ruang ibadat terletak pada lantai 2 (dua) dan 3 (tiga) pada gereja.

\section{Konsep Layout}

Pada Gereja Hati Santa Perawan Maria Tak Bernoda ini organisasi ruang (Ching, 2007) yang digunakan adalah organisasi terpusat dan linier.

a. Organisasi Terpusat

Organisasi ruang terpusat adalah sebuah komposisi yang stabil, terkonsentrasi yang terdiri dari sejumlah ruang sekunder yang dikelompokkan mengelilingi suatu ruang sentral besar dan dominan. Organisasi ruang terpusat 
ini juga sudah umum digunakan pada gereja. Hal tersebut dikatakan oleh beberapa arsitek dunia seperti salah satunya adalah sketsa Leonardo Da Vinci mengenai organisasi ruangideal gereja.

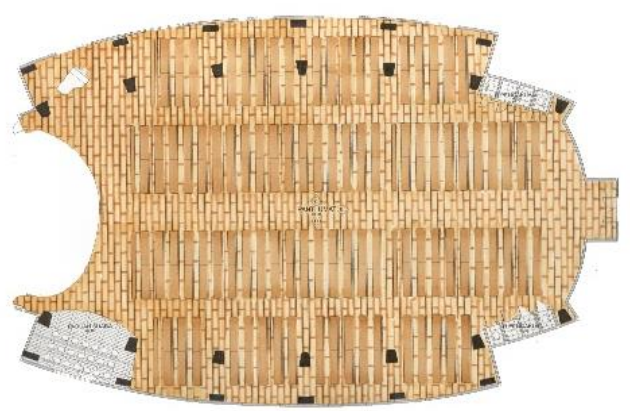

Gambar 4. Layout Panti Umat Lt. Bawah (Sumber: Velika, 2018)

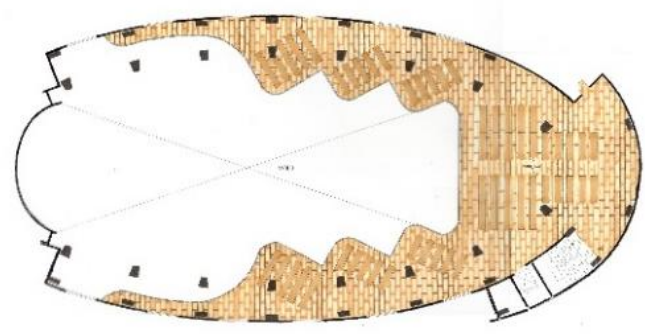

Gambar 5. Layout Panti Umat Lt. Atas (Sumber: Velika, 2018)

Ruangan terpusat dalam gereja adalah ruang ibadat atau badan gereja di mana umat beribadah, dan pastor melayani jemaat. Badan gereja ini dikelilingi oleh ruang pendukung lainnya seperti ruang persiapan, goa maria, ruang pengakuan dosa, area koor, ruang sakristi, ruang permandian.

b. Organisasi Linier

Organisasi linier merupakan serangkaian ruangan yang secara langsung terkait satu sama lain atau dihubungkan melalui sebuah ruang linier. Biasanya ruang memiliki ukuran, bentuk dan fungsi yang serupa. Sifat dari organisasi ruang linier adalah memanjang dan satu arah.

Organisasi ruang linier banyak digunakan untuk ruang kantor, perpustakaan, sekretariat, bendahara, koperasi berdasarkan fungsi dan sifatnya yaitu, sebagai ruang yang sifatnya pelayanan antar- umat manusia agar teratur.

D. Konsep Pola Sirkulasi

Sirkulasi adalah pergerakan melalui ruang. Jalur pergerakan dianggap sebagai elemen penghubung ruang dengan sebuah bangunan atau serangkaian ruang eksterior secara bersama-sama.

Pola sirkulasi dibagi menjadi dua bagian, yaitu sirkulasi horizontal dan vertikal.

a. Sirkulasi Horizontal

1) Pencapaian

Pencapaian yang digunakan dalam perancangan Gereja Hati Santa Perawan Maria Tak Bernoda adalah pencapaian secara langsung mengarahkan ke pintu masuk melalui jalur lurus. 
2) Pintu Masuk

Pintu Masuk Gereja Hati Santa

Perawan Maria Tak Bernoda

menggunakan pintu yang tinggi dan

sedikit lebar dengan arti gereja menyambut umat yang datang dengan senang hati.

3) Konfigurasi Jalur

Konfigurasi jalur yang digunakan pada Gereja Hati Santa Perawan Maria Tak Bernoda adalah konfigurasi linier. Jalur ini tidak hanya terdiri dari satu garis lurus saja melainkan dapat juga berupa garis memotong, bercabang ataupun membentuk sebuah putaran.

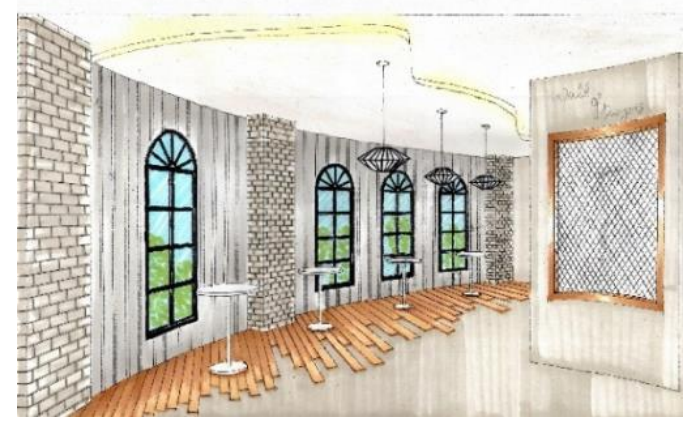

Gambar 6. Lobby Gereja (Sumber: Velika, 2018)

b. Sirkulasi Vertikal

1) Tangga

Tangga dan jalur tangga tersedia untuk pergerakan vertikal jemaat antara lantai sebuah bangunan atau ruang luar.
Perancangan tangga akan dibuat untuk mendukung adanya sirkulasi vertikal menuju badan gereja.

2) Lift

Lift adalah angkutan transportasi vertikal yang digunakan untuk mengangkut orang atau barang.

Bangunan Gereja yang terdiri dari 3 lantai memiliki sirkulasi vertikal lift sebagai fasilitas bagi jemaat untuk menuju ruang ibadah khususnya bagi kaum disabilitas.

\section{E. Konsep Furniture}

Pemilihan furniture dalam perancangan Gereja Katolik Hati Santa Perawan Maria Tak Bernoda akan disesuaikan dengan konsep tema yang digunakan dalam perancangan Gereja Hati Santa Perawan Maria Tak Bernoda. Gaya yang akan diterapkan pada peracangan gereja ini adalah modern vintage maka bentuk furniture yang digunakan akan didesain dengan sedikit bentuk lengkung.

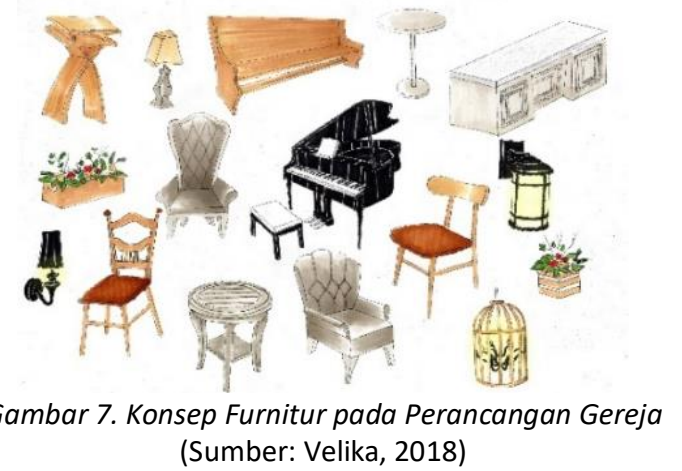




\section{Konsep Material dan Warna}

A. Konsep Material

Konsep material yang digunakan dalam perancangan Gereja Hati Santa Perawan Maria Tak Bernoda akan dipilih berdasarkan citra Gereja. Sebagai contoh bahwa visi Gereja Hati Santa Perawan Maria Tak Bernoda adalah "menjadikan umat kuat dalam iman", maka kata kuat dapat digambarkan dengan penggunaan material tembaga pada area dinding altar dan lantai marmer pada altar.

Pada dinding Gereja menggunakan dinding bata kokoh dan kuat dan dapat di finishing berbagai jenis finishing seperti cat tembok, HPL, wallpaper dan lain-lain. Pada dinding panti imam akan menggunakan batu alam.

Plafon Gereja menggunakan gypsum board yang akan diberikan lukisan awan sebagai lambang bahwa Tuhan hadir dalam peribadatan.

B. Konsep Warna

Konsep warna yang digunakan pada Gereja Hati Santa Perawan Maria Tak Bernoda mengadaptasi dari citra gereja yaitu suci, hangat, dan kekeluargaan. Selain itu juga harus memberikan suasana hangat perjamuan ekaristi yang juga bertujuan untuk mengenang kebaikan pengorbanan Tuhan terhadap umat manusia.

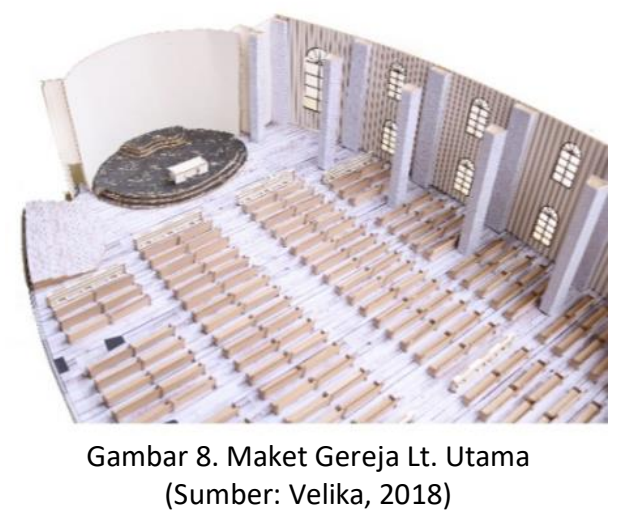

Oleh karena itu, warna yang akan digunakan dalam perencanaan Gereja Katolik Hati Santa Perawan Maria Tak Bernoda adalah warna putih dan warnawarna liturgi, dan warna-warna hangat.

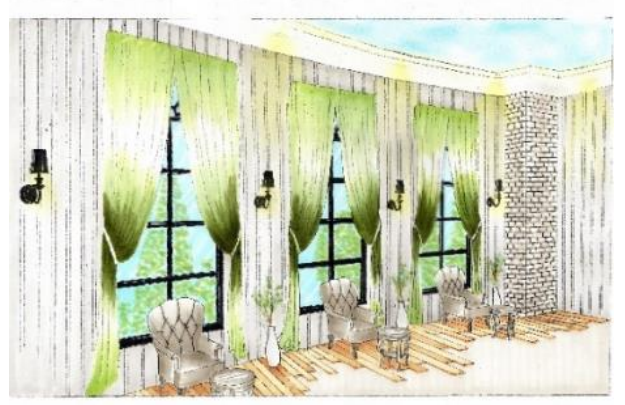

Gambar 9. Penerapan Warna Hangat di Ruang Laktasi (Sumber: Velika, 2018)

\section{Konsep Pengkondisian Ruang}

A. Konsep Pencahayaan

1. Sistem Pencahayaan Alami

Pencahayaan alami dalam perancangan Gereja Hati Santa Perawan Maria Tak Bernoda dilakukan melalui jendela. 
2. Sistem Pencahayaan Buatan

Pencahayaan buatan memiliki dua fungsi yaitu sebagai pencahayaan umum untuk kegiatan sehari-hari dan sebagai dekorasi. (Suspandar, 1999:224)

Pada peracangan Gereja Hati Santa Perawan Maria Tak Bernoda akan menggunakan lampu PL, TL, ledstrip dengan cahaya berwarna kuning yang menyimbolkan kemenangan, kemuliaan, dan kegembiraan. Akan digunakan juga hanging lamp, table lamp pada area panti imam dan spotlight.

\section{SIMPULAN}

Gereja Hati Santa Perawan Maria Tak Bernoda memiliki karakter hangat sebagaimana seorang ibu memberikan perlindungan kepada anak-anaknya. Untuk mencapai suasana sakral ekaristi, maka ruang-ruang gereja harus sesuai dengan kebutuhan ritualnya baik jenis maupun urutannya.

Penggunaan material dan penerapan skema warna pada ruang-ruang utama lebih menekankan kepada kesederhanaan, sebagaimana karakter Bunda Maria sebagai seorang ibu. Sementara untuk ruang-ruang pendukung dapat menerapkan suasana yang lebih ceria untuk mengakomodasi jemaat lain yang lebih muda.

\section{DAFTAR PUSTAKA}

Ching, F. D. (2007). Architecture: Form, Space, and Order. New Jersey: John Wiley \& Sons, Inc.

Indonesia, K. W. (2009). Kompedium Katekismus Gereja Katolik. Jakarta: Penerbit Kanisius.

Kilmer, R., \& Kilmer, W. (2014). Designing Interiors, 2nd Edition. New Jersey: Wilson Learning.

Nurwardani, P. (2016). Buku Ajar Mata Kuliah Wajib Umum: Pendidikan Agama Katolik. Jakarta: Dirjen Pembelajaran dan Kemahasiswaan, Kemenristekdikti.

Perjanjian Baru. (2005). Jakarta: Bible League Internatinal.

Wardani, L. K. (2006). Simbolisme Liturgi Ekaristi dalam Gereja Katolik: Sebuah Konsepsi dan Aplikasi Simbol. Dimensi Interior, 17-25. 